\title{
A Conceptual Model to Address COVID 19 Pandemic
}

\author{
Kavita Surywanshi, PhD \\ Associate Professor \\ D. Y. Patil Institute of MCA and \\ Management, Pune
}

\author{
Pooja Kulkarni, PhD \\ Assistant Professor \\ D. Y. Patil Institute of MCA and \\ Management, Pune
}

\author{
Sheetal G. Patil \\ Assistant Professor \\ D. Y. Patil Institute of MCA and \\ Management, Pune
}

\begin{abstract}
India is a country where many natural disasters are taking place. In disasters all Indians came together \& contribute individually. In COVID 19 pandemic, Donators could not able to reach to needy people due to its contagious disease.

Normal citizen of country also required help for competing daily needs. In view of this study aims at need of common platform which will act as All in One Solution for each problem.

To fight against COVID 19 we all need to integrate. We can design a system where those who want to donate some amount they can donate. Here to increase fund government can appeal organization to contribute through CSR activity. Many people want to donate some help like grocery can contribute. Those who want to give space to help quarantine people they can enroll and contribute. Those who can provide health services they can also contribute. Those who want to work as volunteer they can also register. We can aware of government policies too. NGO can also work here. Those wants help like person who is quarantine or group quarantine, or society needs can enroll themselves.
\end{abstract}

We all can connect to fight against COVID 19 as a ONE Platform.

\section{Keywords}

Covid-19, NGO, Corona virus.

\section{INTRODUCTION}

Corona virus is virus which cause illness in humans as well as animals. In humans' beings due to corona virus infections varies from respiratory like cold, cough to major disease Middle East Respiratory Syndrome (MERS) and Severe Acute Respiratory Syndrome (SARS).

COVID-19 is the transferable disease produced by the corona virus. This is new virus and it were totally unknown before December 2019. ${ }^{[1]}$

COVID 19 pandemic started in the December 19, in India first patient found in late January 2020. The todays situation where growth of Entire country stopped down almost since last 65 days where no Economic as well as Personal growth.

Since last three months we are fighting with the disease where no medicine available and which can spread through human contact therefore Govt. of India lockdown entire country and ask all citizen to be at home with slogan "Stay Home Stay Safe" further government children below 10 years of age and citizen above 65 years should take added care and should not leave home.

In such pandemic situation only Medical Practitioner, policeman and cleaning department working day and night to control the situation.
The average age of Indian citizen is between 25 to 45 age group and as per COVID pandemic record people between this age group can cure if they not infected with any other disease but due to non-availability of platform and guideline people of this age group cannot able to help the needy person,

If we try to write definition of needy it can be written by many ways such as

1. Older Citizen of India who leave alone

2. Older people leaving in second home

3. Child leaving in childcare unit

4. Quarantine person who didn't have any symptom

5. Infected people (with proper care and training)

\subsection{History of Covid 19}

Originally, scientists believed the virus may have developed from animals like bats, and pangolins. However, genomic judgements advise that SARS-Cov-2 virus was the result of recombination among two viruses. To find origin of Covid 19 many scientists are still working. But in general, we say that virus seems to be natural and has animal origin. In December 2019 this virus spread infection in human to human. WHO study shows that first 41 cases are confirmed of Covid 19 by $1^{\text {st }}$ December 2019. Human to human transmission of covid 19 was confirmed by WHO and Chinese authorities by $20^{\text {th }}$ January $2020 .^{[2]}$

\subsection{World Records of Covid 19}

World records till $30^{\text {th }}$ April 2020 shows that total coronavirus cases are 3,221,653. Total deaths are 228,267 and 1,005,408 are recovered.

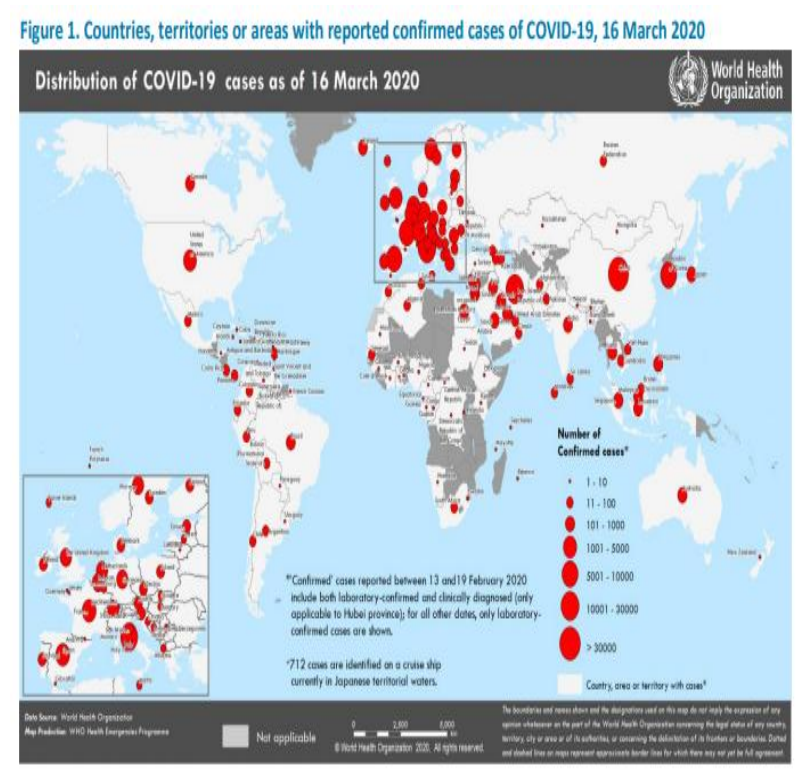


(Source:https://www.who.int/docs/defaultsource/coronaviruse/situation-reports/20200316-sitrep-56covid-19.pdf?sfvrsn=9fda7db2_6)

Above figure shows countries, and areas reported confirm cases of Covid 19 of world as on 16th March 2020.

Particularly in India total corona virus cases are 23651, 1074 deaths and 8324 are cured dated $30^{\text {th }}$ April 2020. ${ }^{[3]}$

\subsection{Nation Lock Down}

On 24 March 2020 the Indian Government under Prime Minister Narendra Modi well-ordered countrywide lockdown for 21 days by limiting measure of the entire 1.3 billion population of India, as a precautionary measure in contradiction of the corona virus pandemic in India. It was well-ordered after 14 hours public curfew dated 22nd March 2020. This lockdown was placed when corona virus confirms 500 cases in India.

During tis lockdown government observes growh rates of the pandemic on hourly basis, day wise week wise.

Near to end of lockdown period state government and other advisory committees suggest lockdown extension. Some states government like Maharashtra, west Bengal, Karnataka, Telangana, Punjab, odisha extended lockdown till 1st may 2020.

On 14th April 2020 Prime Minister Narendra Modi extended the nationwide lockdown till 3rd May 2020, with a provisional relaxation afterwards 20 April for the areas wherever the spread has been controlled.[4]

After this Prime Minister Narendra Modi extended the nationwide lockdown from 3rd May 2020 till 17th may 2020, and lastly from 17th may 2020 till 31st may 2020.

\section{PROBLEM STATEMENT}

India needs to produce a response to the disaster; we want to pool in \& assemble all the resources in the country. This desires to start with the government, then saturate down to cover public, private and civil society person. For this there is needs to have a model of integration, wherein civil society may aid the government's efforts. Now, however, there is no such model.

In the pandemic of COVID 19 we are fighting with virus who does not have any medicine to resolve the infected person can not identified easily and even it can be spread even infected person knowing he is infected. The only medicine is to keep yourself quarantine because of same many problem faced by common people as well as infected people even government facing huge problem to control this virus.

The researcher found that people leaving in society can't extend helping hand to infected person or normal person who can't help himself due to lockdown in society, in addition we can't contribute to government.

Aim of this research paper is to analyze situation of covid 19 and find some solution against covid 19 pandemic which will help patients, quarantine people, and all citizens of nation. It also aims to help government financially. It connects all the people at one platform so they can help each other.

\section{LITERATURE REVIEW}

According to Interim guidance dated 19 march 2020 suggest that "Considerations for quarantine of individuals in the context of containment for coronavirus disease (COVID-19)". In this article WHO director suggest that quarantine is one of the solution to avoid human to human transmission of covid 19. He also suggest some recommendations while quarantine a person. This article also focus on control measures and minimum infection prevention.[5]

Ahmet Riza Sahin,1 Aysegul Erdogan,2 Pelin Mutlu Agaoglu,2 Yeliz Dineri,2 Ahmet Yusuf Cakirci,2 Mahmut Egemen Senel,3 Ramazan Azim Okyay2 , Ali Muhittin Tasdogan4 Says "2019 Novel Coronavirus (COVID-19) Outbreak: A Review of the Current Literature". This study gives a preliminary opinion regarding the disease, the ways of treatment, and preventions to be taken in this preliminary stage of COVID-19 outbreak.[6]

According to Jing Zhao, MD, PhD; Anthony Rudd , FRCP (Lond); Renyu Liu , MD, PhD in Editorial wrote "Challenges and Potential Solutions of Stroke Care During the Coronavirus Disease 2019 (COVID-19) Outbreak". This article studied southern china hospitals for covid 19 disease. Many measures was taken concerning the spread of the covid 19 , isolation wards for the quarantine persons, community lockdown, appending monotonous outpatient clinics. More than 40000 medical experts from China have been sent to the epicenter of the disease.[7]

Karen Hänel, Thomas Stangler, , Matthias Stoldt \& Dieter Willbold publish article in Journal of Biomedical Science (2006), titled "Solution structure of the X4 protein coded by the SARS related coronavirus reveals an immunoglobulin like fold and suggests a binding activity to integrin I domains". This article set out to govern the three angles of answerable ectodomain of this type I transmembrane protein by nuclear magnetic resonance spectroscopy. This paper identifies structure of replication of virus and it also predict some functions based on this structure.[8]

Government of India introduces many application such Aarogyasetu, COVID-19 Quarantine Monitor - Tamil Nadu, COVA Punjab, SAHYOG, MyGov, Aarogya Setu but these are specific application mainly used to check COVID Patient located nearby us and status in our area there is no specific application which can cover all the needs.

Indias Prime Minister honorable Narendra Modi discuss his views regarding fight against covid 19 pandemic in Mann ki Baat dated 26th April 2020. He said Indias fight against pandemic is people oriented where people help each other according to their individual capacity. Some people donating food, some donating mask, some people are offering medical services. So we need one one framework where all people can connected to each other and help needy one.

While developing integrated solution payTM app can be consider as a reference where it offers many financial services like DTH recharge, bill payment, money transfer, etc. PayTM also offers ecommerce for purchasing \& selling goods. It gives offers too in the form of coupons. It also offers payTM bank for banking services. Researcher think same kind of app development which offers variety of services to fight against covid 19 pandemic solution.

Based on literature review author find gap that there is not any medium through which persons can help each other. Help can be financial, it may be services provide, it may me in terms of food or grocery. So this paper gives one common platform where anyone can registered and help others or can get help. 


\section{DISCUSSION OF SOLUTION TO PROBLEM}

COVID 19 where nation is lockdown and we are almost quarantine, only online interaction can help us to be in connected. In this scenario researcher think a software prototype which can implemented through all possible platform like Computer Application, Mobile Application, IVR System Integration, etc can be one of the solution for this pandemic

The model suggested by researcher is broader view of the solution and each module can be integrated or independently developed as per requirement and need of current hour but interned system will be useful, further the other application build by Govt of India like SETU can be included in this system.

The business model of any organization based on 4 M's viz Men, Money, Material and Machine. Researcher thing COVID 19 pandemic contain business model where 4M's viz Men, Money, Material and Machine through a software platform which can help to COVID 19 pandemic in which

A. Men : It's very difficult to extend help for common men if we consider case of Govt of Maharashtra the minster ask central govt to send arm force to extend help but if we utilize proper channel and study COVID 19 we will found that the person who has additional disease and then affected by COVID 19 then its difficult to that person to cruel but person who is in young age group and disinfected with other disease and ready to work as volunteer can register them self on our software solution can be utilize

B. Money : additional to $\mathrm{CM}$ and PM relief fund can we ask all the organization to spend their $2 \%$ profit to this cause it will be resolve maximum of fund problem as its mandatory for all the organization to spend 2\% pf profit as Corporate Social Responsibility this money should be tax free which can generate fund on quick basis

C. Material : People who have land near by city area can make available on lease basis or as contribution to set up quarantine center, all airport in India mostly are outside city so if we create quarantine center near by airport it can help to start air service in India and abroad. In addition, rather than taking stadium for setting up hospital and quarantine center, if this center build on remote location may provide chance to reduce affected Popole our solution encourages and motivate people for same

D. Machine: the collected amount can be used to purchase oxygen mask and other essential things

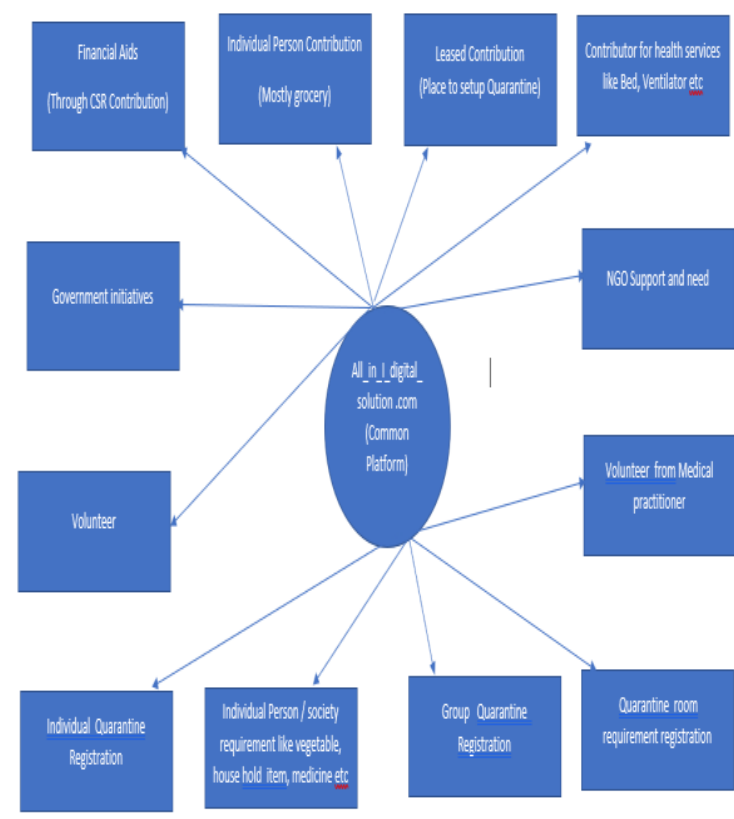

Fig: Proposed Solution

The solution is based on 12 modules:

i. Financial Aids:

As of now we are expecting financial help from individual to Prime minister relief fund/ Chief Minister relief fund but as a government regulation every organization need to contribute $2 \%$ of profit for social responsibility (CSR), these $2 \%$ at least for the month of April May can be use for Covid 19 relief purpose.

ii. Individual person contribution: (mostly grocery) The contribution required from normal citizen mostly in the form of grocery which can be utilize to provide for home quarantine or another normal citizen (physically disable, Senior Citizen or medically unfit citizen)

iii. Leased Contribution (Place to setup Quarantine) In the scenario of incasing COVID - 19 patients, we required isolation ward where we can keep Quarantine people or 14 days isolation ward to keep patient after s/he get recover, the contributor for providing place to build these kinds of room a side of city area is much needed as much

iv. Contributor for health services

Although someone provide space to build isolation ward, we required support to prepare the room in the form of Bed's, Oxygen Mask etc. in addition we also required Blood Donor

v. Volunteer

The most important component is volunteer, who can help affected citizen to provide required facility.

vi. Volunteer from Medical practitioner

To support isolation ward as well as to support doctors we required Volunteer from Medical practitioner (as truly extend help by Govt. of Maharashtra)

The above-mentioned parameter will help to needy individual if and only if we aware

vii. Individual Quarantine

A person who is in isolation either due to near one of infected citizen or traded from highly infected area need help for his routine as could not leave his place for at least 14 days 
viii. Group Quarantine Registration

Sealed area in which we found COVID -19 affected person needs daily verges for routine and as the area is sealed we required someone who can reach essential items to near by location

ix. Individual Person / society

Because if lockdown Old age citizen, medically infit person and physically disabled person required help for daily verges as well as for medicine and physical concert, need to be provided as and when required

\section{x. Quarantine room requirement}

Medical practitioner needs to isolate person or group of persons outside city or crowded area where these citizens can be under observation as well as can do the daily routine

xi. Government initiatives

All the citizen should aware about government initiatives which can run at different level

xii. NGO Support and need

To run campaign against COVID-19 we required support form NGO's as well as we can help NGO's where they required.

\section{SOCIAL IMPLICATION}

Researcher proposed a model based on assumption and address all the major concern; this model can be utilizing as prototype for creating software based architecture where following things can be addressed:

1. Ease of use: the platform should be easy to use, researcher things this platform execute in all the modes which available like android based application, web-based application, telecall based application etc.

2. Perceived usefulness: the application should be portable and can transfer to all regional languages

3. Behavior Intention: the system should connect to all the stakeholder.

- Proposed solution will help government to raise funds.

- Any citizen who want to contribute something just must look into all in one solution to see who want help even kind of help needed.
- Normal citizen who have space can utilize that for needy quarantine people.

- $\quad$ NGO will also come to know which area people need help on priority and type of need.

- Senior citizens, weak people can get help through this solution.

- Volunteer service can be easily served on priority wise.

\section{CONCLUSION}

After considering all these things we should have a common platform where all the information available and we can fight against COVID-19 most effectively.

The researcher discusses about the software solution where people who need to work as volunteer people, who need help, people who can provide space on lease or to make use for some time can register on web portal. The company who want to contribute will contribute through the application and the authority may be finance department, development department and health department can make awareness for the application and provide the relief to individual.

The application should create with multilanguage and multiplatform based as well as IVR based tele caller system should be part of the application for ease of use specifically in rural areas.

\section{REFERENCES}

[1] https://www.mohfw.gov.in/pdf/FAQ.pdf

[2] https://en.wikipedia.org/wiki/Coronavirus_disease_2019 \#History.

[3] https://www.mygov.in/covid-19.

[4] https://en.wikipedia.org/wiki/2020_coronavirus_lockdow n_in_India.

[5] https://apps.who.int/iris/bitstream/handle/10665/331497/ WHO-2019-nCoV-IHR_Quarantine-2020.2-eng.pdf.

[6] https://s3.amazonaws.com/academia.edu.documents/

[7] https://www.ahajournals.org/doi/pdf/10.1161/STROKEA HA. 120.029701 .

[8] https://link.springer.com/content/pdf/10.1007/s11373005-9043-9.pdf. 